\title{
PENGARUH PARAMETER PENGONTROL DALAM MENEKAN PENYEBARAN PENYAKIT FLU BURUNG
}

\author{
Rina Reorita, Niken Larasati, dan Renny \\ Program Studi Matematika, Jurusan MIPA, Fakultas Sains dan Teknik, \\ Universitas Jenderal Soedirman Purwokerto, Indonesia
}

\begin{abstract}
Indonesia has been being a country which has the most victims of avian influenza case. Avian influenza is caused by influenza virus H5N1 type. This virus can be transmitted from infected poultry to susceptible poultry and infected poutry to susceptible human. This paper describes an SIR (Susceptible, Infection, Recovery) mathematic model for the spread of avian influenza disease. The basic reproduction number will be obtained for analyzing what are the factors that can influence the epidemic. By the Pontryagin Maximum Principle, it can be seen how is the influence of vaccine as a control to the spread of disease.
\end{abstract}

Keywords: avian influenza, SIR, Pontryagin Maximum Principle

\section{Pendahuluan}

Penyebab flu burung pada unggas yang sangat ganas dan menular ke manusia pada wabah akhir-akhir ini dinyatakan sebagai virus influenza A subtipe H5N1. Awalnya flu burung hanya menyerang unggas, kemudian virus penyebab flu burung mengalami mutasi sehingga bisa menginfeksi manusia (Yuliarti, 2006). Sejauh ini belum ada kasus yang memperlihatkan transmisi virus dari manusia ke manusia (Derouich and Boutayeb, 2008). Karena sebagian besar penduduk Indonesia bekerja pada sektor peternakan unggas, infeksi virus ini tidak boleh dipandang remeh. Berdasarkan data WHO pada tahun 2004, virus flu burung sebagian besar menginfeksi orang-orang yang bekerja di peternakan unggas (Situngkir, 2004).

Derouich (2008) menurunkan model penyebaran penyakit flu burung dengan memperhatikan populasi manusia dan unggas. Pada model tersebut, 
tingkat kematian alami dan tingkat kematian karena penyakit pada unggas dianggap sama. Sementara itu, Zhao (2009), mengkonstruksi model dengan menambahkan variabel vaksin pada manusia yang rentan.

Selain pemberian vaksin pada manusia, virus flu burung dapat juga dikontrol dengan memberikan suatu perlakuan khusus pada unggas, yang salah satunya adalah dengan pemberian vaksin pada unggas (Yuliarti, 2006). Pada makalah ini, penulis tertarik untuk mengkaji model penyebaran flu burung yang dibahas oleh Derouich dengan menambahkan kontrol vaksin pada unggas yang rentan terhadap penyakit flu burung. Penambahan variabel pengontrol pada model berupa penggunaaan vaksin pada unggas yang rentan, diharapkan dapat digunakan untuk menekan penyebaran penyakit tersebut.

\section{Model Matematika}

Model penyebaran penyakit flu burung pada makalah ini berdasarkan model SIR (Derouich, 2008), tetapi tingkat kematian alami tidak sama dengan tingkat kematian karena penyakit baik pada manusia maupun unggas.. Pada model ini, sistem dibagi menjadi dua populasi, yaitu populasi manusia dan populasi unggas. Populasi manusia $(N)$ dibagi menjadi tiga kelompok, yaitu kelompok manusia sehat yang rentan flu burung ( $S$ ), kelompok manusia terinfeksi ( $I$ ), dan kelompok manusia yang sembuh dari flu burung $(R)$. Kelompok manusia yang sembuh memiliki kekebalan sementara terhadap flu burung dan mempunyai kemungkinan untuk kembali menjadi kelompok manusia rentan. Sedangkan populasi unggas ( $N_{0}$ ) dibagi menjadi dua kelompok, yaitu kelompok unggas sehat yang rentan flu burung $\left(S_{0}\right)$ dan kelompok unggas yang terinfeksi flu burung $\left(I_{0}\right.$ ). Kelompok unggas terinfeksi diasumsikan tidak akan sembuh dari flu burung.

Penambahan jumlah kelompok manusia rentan dipengaruhi oleh faktor imigrasi dan kelahiran dengan laju $\Lambda$ dan tingkat perpindahan kelompok manusia yang sembuh menjadi kelompok manusia rentan sebesar $\delta$. Terjadinya kontak antara kelompok manusia rentan dengan kelompok unggas terinfeksi dengan tingkat $\beta$ menyebabkan kelompok manusia rentan berubah menjadi kelompok 
manusia terinfeksi. Pengurangan jumlah pada kelompok manusia rentan juga dipengaruhi oleh tingkat kematian alami sebesar $\mu$. Pengurangan jumlah pada kelompok manusia terinfeksi dipengaruhi oleh tingkat kematian karena penyakit flu burung $(\alpha)$ dan kemungkinan kelompok manusia terinfeksi sembuh dari flu burung $(\gamma)$.

Penambahan jumlah kelompok unggas rentan dipengaruhi adanya tingkat kelahiran alami sebesar $\sigma$. Sedangkan pengurangan jumlah pada kelompok ini dipegaruhi oleh tingkat kematian alami sebesar $\mu_{0}$, tingkat kontak antara kelompok unggas rentan dengan kelompok unggas terinfeksi sebesar $\beta_{0}$. Penambahan jumlah kelompok unggas terinfeksi dipengaruhi oleh tingkat kontak $\beta_{0}$, sedangkan pengurangan pada kelompok ini dipengaruhi oleh tingkat kematian karena penyakit sebesar $\theta$.

Diagram kompartemen untuk penyebaran penyakit flu burung seperti pada Gambar 2.1 .

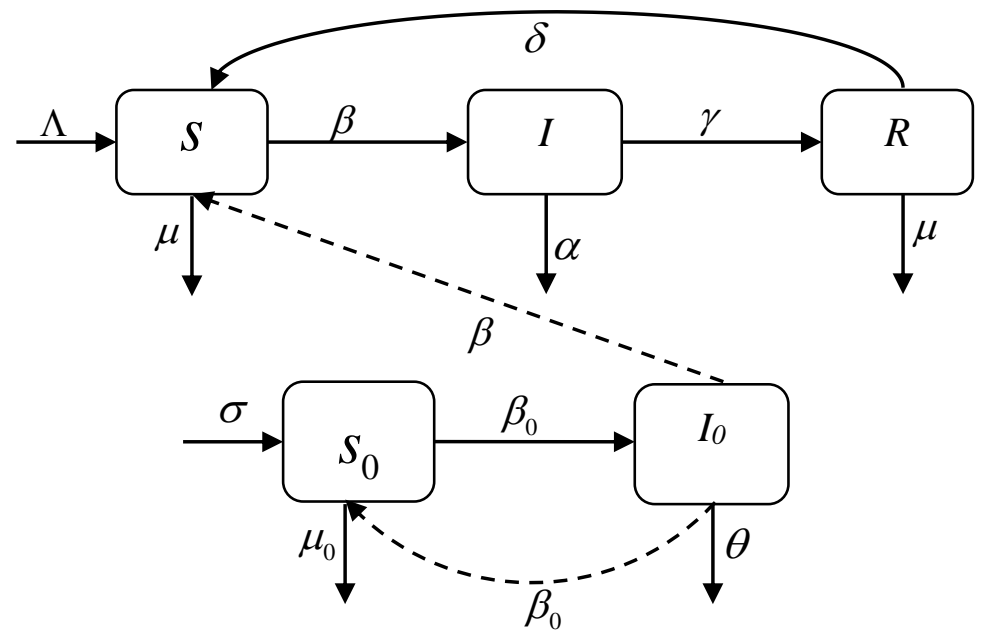

Gambar 2.1 Diagram kompartemen penyebaran penyakit flu burung

Berdasarkan diagram kompartemen pada Gambar 2.1, diperoleh model penyebaran penyakit flu burung, yaitu

$$
\frac{d S}{d t}=\Lambda+\delta R-\left(\mu+\frac{\beta I_{0}}{N_{0}}\right) S
$$




$$
\begin{aligned}
& \frac{d I}{d t}=\frac{\beta S I_{0}}{N_{0}}-(\alpha+\gamma) I \\
& \frac{d R}{d t}=\gamma I-(\mu+\delta) R \\
& \frac{d S_{0}}{d t}=\sigma N_{0}-\left(\mu_{0}+\frac{\beta_{0} I_{0}}{N_{0}}\right) S_{0} \\
& \frac{d I_{0}}{d t}=\frac{\beta_{0} S_{0} I_{0}}{N_{0}}-\theta I_{0}
\end{aligned}
$$

dengan $N=S+I+R$ dan $N_{0}=S_{0}+I_{0}$.

Proses analisis akan lebih mudah dilakukan jika dibentuk sistem baru dengan menggunakan proporsi (perbandingan), yaitu

$$
\begin{aligned}
& \frac{d s}{d t}=\mu+\delta r-\left(\mu+\beta i_{0}\right) s \\
& \frac{d i}{d t}=\beta s i_{0}-(\alpha+\gamma) i \\
& \frac{d r}{d t}=\gamma i-(\mu+\delta) r \\
& \frac{d i_{0}}{d t}=\beta_{0} i_{0}-\beta_{0} i_{0}{ }^{2}-\theta i_{0}
\end{aligned}
$$

dengan

$$
s=\frac{S}{N}=\frac{S}{\Lambda / \mu}, \quad i=\frac{I}{N}=\frac{I}{\Lambda / \mu}, \quad r=\frac{R}{N}=\frac{R}{\Lambda / \mu}
$$

dan $\quad s_{0}=\frac{S_{0}}{N_{0}}, \quad i_{0}=\frac{I_{0}}{N_{0}}$.

\subsection{Titik Kesetimbangan dan Angka Rasio Reproduksi Dasar}

Model penyebaran penyakit flu burung mempunyai dua titik kesetimbangan yaitu titik kesetimbangan bebas penyakit dan endemik. Titik kesetimbangan bebas penyakit $T_{1}=(1,0,0,0)$ stabil asimtotis jika $\beta_{0}<\theta$, sedangkan titik kesetimbangan endemik $T_{2}=\left(s^{*}, i^{*}, r^{*}, i_{o}^{*}\right)$, dengan 


$$
\begin{aligned}
& s^{*}=\frac{(\alpha+\gamma)(\mu+\delta) \beta_{0}}{\beta\left(\beta_{0}-\theta\right)\left\{(\alpha+\gamma)+\frac{\delta \alpha}{\mu}\right\}+(\alpha+\gamma)(\mu+\delta) \beta_{0}} \\
& i^{*}=\frac{\beta(\mu+\delta)\left(\beta_{0}-\theta\right)}{\beta\left(\beta_{0}-\theta\right)\left\{(\alpha+\gamma)+\frac{\delta \alpha}{\mu}\right\}+(\alpha+\gamma)(\mu+\delta) \beta_{0}} \\
& r^{*}=\frac{\beta \gamma\left(\beta_{0}-\theta\right)}{\beta\left(\beta_{0}-\theta\right)\left\{(\alpha+\gamma)+\frac{\delta \alpha}{\mu}\right\}+(\alpha+\gamma)(\mu+\delta) \beta_{0}} \\
& i_{o}^{*}=\frac{\beta_{0}-\theta}{\beta_{0}}
\end{aligned}
$$

akan stabil asimtotis jika $\theta<\beta_{0}$. Selanjutnya, dengan menggunakan metode pendekatan operator generasi selanjutnya diperoleh angka rasio reproduksi dasar dari model penyebaran penyakit flu burung yaitu $R_{0}=\frac{\beta_{0}}{\theta}$.

\subsection{Simulasi Model}

Simulasi model dilakukan untuk mengetahui perilaku model pada persekitaran titik kesetimbangan bebas penyakit dan titik kesetimbangan endemik. Nilai-nilai parameter yang digunakan untuk simulasi di titik kesetimbangan bebas penyakit $T_{1}=(1,0,0,0)$ adalah $\Lambda=200 ; \mu=0,05 ; \mu_{0}=0,08 ; \beta=0,06 ;$ $\beta_{0}=0,002 ; \alpha=0,07 ; \delta=0,1 ; \gamma=0,02 ; \sigma=0,001 ; \theta=0,2$. Syarat awal yang diberikan adalah $S(0)=2400, I(0)=800, R(0)=400, N_{0}(0)=1000$, $I_{0}(0)=500$.

Hasil simulasi dapat dilihat pada Gambar 2.2 berikut ini. 


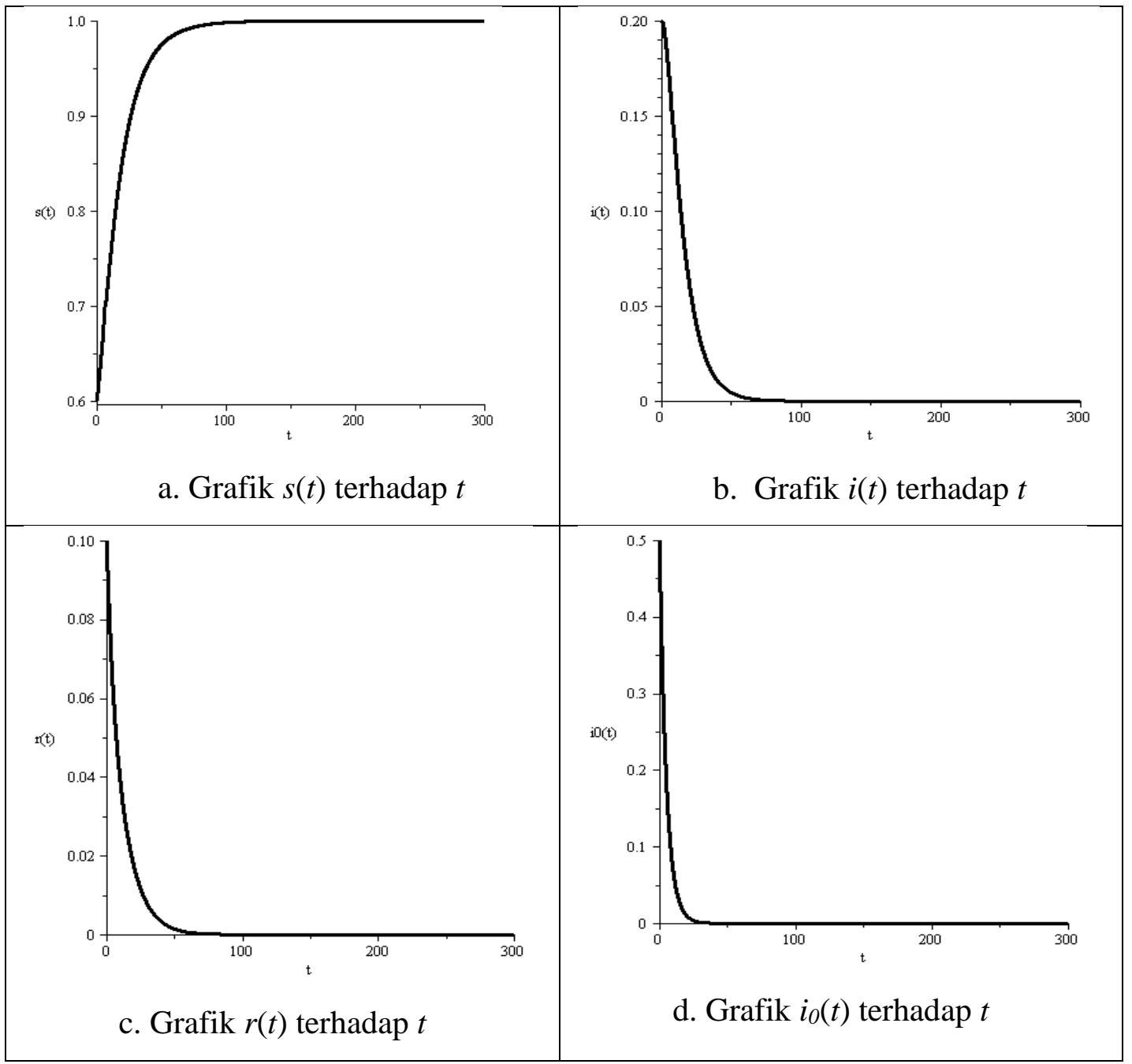

Gambar 2.2 Grafik $s(t), i(t), r(t), i_{0}(t)$ terhadap $t$ untuk titik kesetimbangan bebas penyakit $(1,0,0,0)$

Berdasarkan hasil simulasi pada Gambar 2.2, untuk $R_{0}=0,01<1$ proporsi kelompok manusia rentan akan menuju 1, proporsi kelompok manusia terinfeksi, kelompok manusia yang sembuh dan kelompok unggas terinfeksi akan menuju 0 untuk jangka waktu yang lama. Hal ini berarti tidak terjadi epidemi pada populasi.

Nilai-nilai parameter yang digunakan untuk simulasi di titik kesetimbangan endemik adalah $\Lambda=200 ; \mu=0,05 ; \mu_{0}=0,002 ; \beta=0,06$; $\beta_{0}=0,2 ; \alpha=0,09 ; \delta=0,1 ; \gamma=0,02 ; \sigma=0,001 ; \theta=0,08$. Kemudian diberikan 
syarat awal $S(0)=3800, \quad I(0)=500, R(0)=0, N_{0}(0)=1000, I_{0}(0)=25$. Hasil simulasi dapat dilihat pada Gambar 2.3 berikut ini.

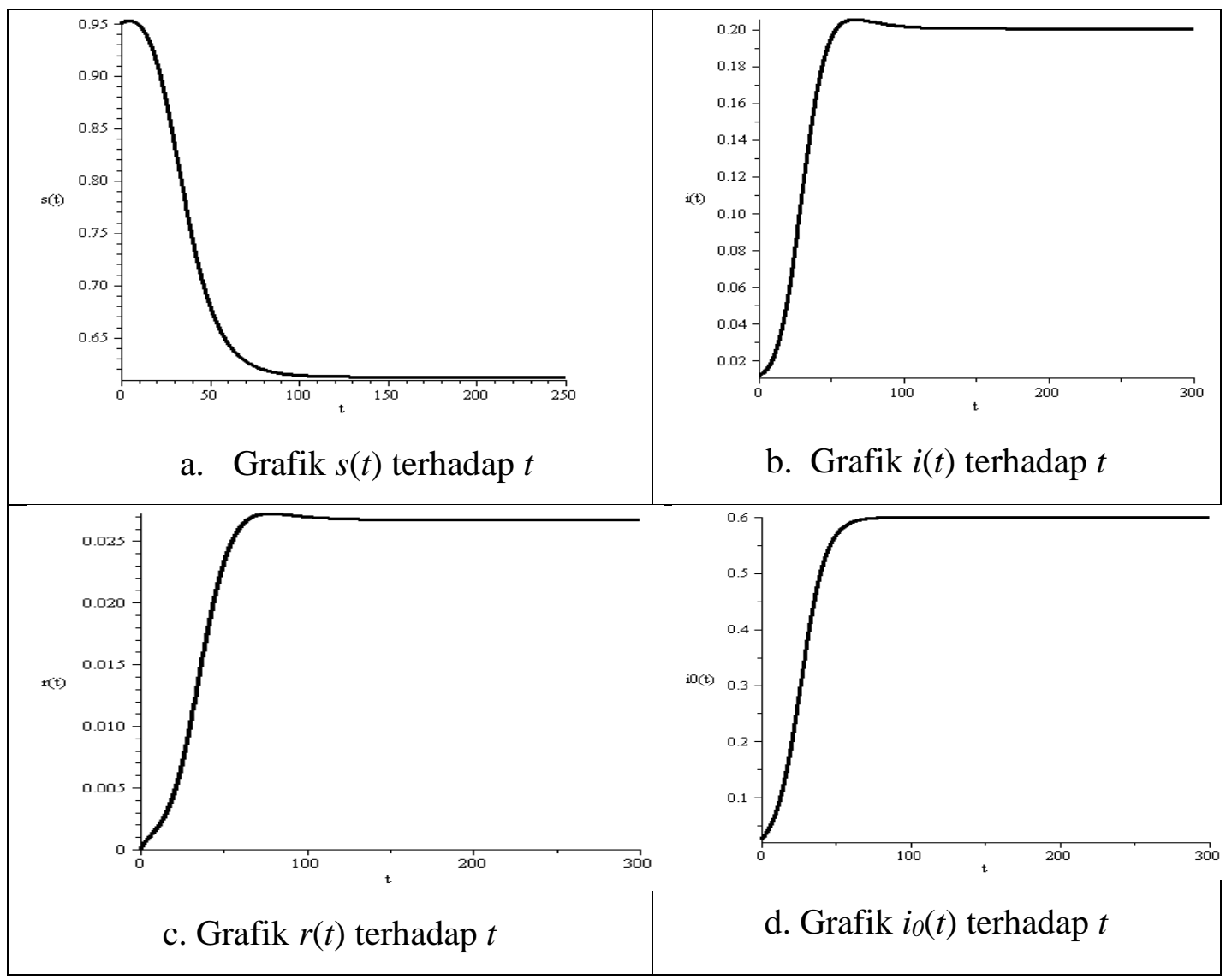

Gambar 2.3 Grafik $s(t), i(t), \quad r(t), i_{0}(t)$ terhadap $t$ untuk titik kesetimbangan endemik $T_{2} \approx(0,6125 ; 0,2 ; 0,0267 ; 0,6)$.

Berdasarkan hasil simulasi pada Gambar 2.3, untuk $R_{0}=2,5>1$ proporsi kelompok manusia rentan akan menuju 0,6125, proporsi kelompok manusia terinfeksi akan menuju 0,2, proporsi kelompok manusia yang sembuh akan menuju 0,0267 dan proporsi kelompok unggas terinfeksi akan menuju 0,6 untuk jangka waktu yang lama. Hal ini berarti terjadi epidemi pada populasi.

\subsection{Pengaruh Variabel Kontrol terhadap Model}

Implementasi vaksin pada unggas merupakan salah satu cara untuk mengontrol penyebaran penyakit flu burung. Karena vaksin diterapkan hanya 
pada unggas, maka untuk penyederhanaan, pengaruh kontrol dapat dilihat pada sistem unggas saja. Persamaan state yang menggambarkan model penyebaran penyakit flu burung pada unggas adalah sebagai berikut:

$$
\begin{aligned}
& \frac{d s_{0}}{d t}=\sigma-\left(\mu_{0}+\beta_{0} i_{0}\right) s_{0}-u \\
& \frac{d i_{0}}{d t}=\beta_{0} i_{0} s_{0}-\theta i_{0} .
\end{aligned}
$$

Pada keadaan awal, diasumsikan bahwa proporsi unggas yang terinfeksi adalah $i_{0}(0)=a>0$, dengan $s_{0}(0)=1-a$. Semakin banyak unggas yang terinfeksi, maka akan semakin besar potensinya untuk menginfeksi seluruh populasi. Tujuan dari vaksin ini adalah mengurangi proporsi kelompok unggas terinfeksi sampai suatu nilai $\varepsilon$ yaitu bilangan positif yang sangat kecil, dengan $\varepsilon<a$, dan interval waktu yang tidak ditentukan (free terminal time).

Fungsi kontrol (dalam hal ini vaksin) dinyatakan oleh $u$. Fungsi ongkos memuat suatu komponen yang menaikkan nilai $u$ secara kuadratik. Hal ini mengindikasikan bahwa ongkos akan besar jika vaksin dilakukan secara besarbesaran. Bentuk fungsi kontrol dapat dirumuskan sebagai berikut:

$$
J=\int_{0}^{t_{1}} u^{2} d t
$$

Nilai awal untuk $i_{0}$ dan $s_{0}$ telah ditentukan sebelumnya. Pada keadaan awal, $i_{0}(t)$ haruslah merupakan fungsi naik, sehingga dari persamaan (11) diperoleh syarat $\beta_{0}(1-a)-\theta>0$. Jika sebaliknya, maka tidak mungkin penyakit menyebar secara signifikan.

Pada saat akhir, $i_{0}\left(t_{1}\right)=\varepsilon$, karena $i_{0}$ akan turun secara eksponensial ketika $\beta_{0} s_{0}<\theta$, sehingga perlu waktu tak hingga untuk $i_{0}$ agar berkurang hingga sama dengan nol. Untuk proporsi populasi $s_{0}$ ada dua kemungkinan, yaitu $s_{0}\left(t_{1}\right)>0$ dan $s_{0}\left(t_{1}\right)=0$. Untuk $s_{0}\left(t_{1}\right)=0$, jelas bahwa pada saat $t_{1}$ semua unggas di dalam populasi tersebut kebal. Selanjutnya, berdasarkan kondisi transversal $z_{1}\left(t_{1}\right)=0$, untuk $s_{0}\left(t_{1}\right)=0$. 
Fungsi Hamiltonian untuk persamaan state tesebut adalah sebagai berikut:

$$
H=-u^{2}+\left[\sigma-\left(\mu_{0}+\beta_{0} i_{0}\right) s_{0}-u\right] z_{1}+\left[\beta_{0} i_{0} s_{0}-\theta i_{0}\right] z_{2}
$$

dengan persamaan co-state sebagai berikut:

$$
\begin{aligned}
& \frac{d z_{1}}{d t}=-\frac{\partial H}{\partial s_{0}}=\left(\mu_{0}+\beta_{0} i_{0}\right) z_{1}-\beta_{0} i_{0} z_{2} \\
& \frac{d z_{2}}{d t}=-\frac{\partial H}{\partial i_{0}}=\beta_{0} i_{0} z_{1}-\left(\beta_{0} s_{0}-\theta\right) z_{2} .
\end{aligned}
$$

Supremum dari $H$ dicapai apabila dipilih $u=-\frac{1}{2} z_{1}$ ketika $s_{0}>0$ dan $u=0$ ketika $s_{0}=0$. Misalkan, $s_{0}=0$ pada saat $t=t_{2}$, maka dari $t=0$ ke $t=t_{2}$ diterapkan $u=-\frac{1}{2} z_{1}$, sedangkan dari $t=t_{2}$ ke $t=t_{1}$ diterapkan $u=0$.

Apabila digunakan Pontryagin Maximum Principle, yaitu $H=0$, sepanjang trajektori optimal pada $t=t_{1}$, maka diperoleh

$$
\left[\beta_{0} i_{0} s_{0}-\theta i_{0}\right] z_{2}=0 \text {. }
$$

Sedangkan solusi variabel state dan co-state untuk selang waktu $t_{2}$ sampai $t_{1}$ adalah sebagai berikut:

$$
\begin{aligned}
& s_{0}(t)=0 \\
& i_{0}(t)=I_{0} e^{-\theta\left(t-t_{2}\right)} \\
& z_{2}(t)=e^{\theta t}
\end{aligned}
$$

dengan $i_{0}\left(t_{2}\right)=I_{0}$.

Nilai $t_{1}$ dapat diperoleh dari persamaan (18), yaitu sebagai berikut:

$$
t_{1}=t_{2}+\frac{1}{\theta} \ln \frac{I_{0}}{\varepsilon}
$$

dengan $t_{1}$ adalah waktu akhir penggunaan vaksin, sedangkan $t_{2}$ adalah waktu dimana kelompok unggas yang rentan menjadi nol.

Jika $J_{2}$ menyatakan nilai integral fungsi ongkos sepanjang 0 sampai dengan $t_{2}$, maka fungsi ongkos optimal diperoleh sebagai berikut: 


$$
\begin{aligned}
J=\int_{0}^{t_{1}} u^{2} d t \Leftrightarrow J_{1}+J_{2} & \Leftrightarrow J=\int_{0}^{t_{1}} u^{2} d t+\int_{t_{1}}^{t_{2}} u^{2} d t \\
& \Leftrightarrow J=\int_{0}^{t_{1}}\left(-\frac{1}{2} z_{1}\right)^{2} d t+\int_{t_{1}}^{t_{2}} 0 d t
\end{aligned}
$$

maka

$J=\frac{1}{4} \int_{0}^{t_{1}} z_{1}^{2} d t+C$

Persamaan (21) ini belum dapat memperlihatkan secara tepat berapa ongkos minimum yang dicapai selama penggunaan vaksin dari waktu 0 sampai dengan $t_{1}$. Akan tetapi, pengaruh kontrol ini dapat dilihat melalui plot gambar untuk persamaan (10), (11), (14), dan (15). Plot gambar seperti yang ditunjukkan oleh Gambar (2.4) diperoleh dengan menggunakan program Maple 9,5 dan mengambil $s_{0}(0)=500, i_{0}(0)=20, z_{1}(0)=100$, dan $z_{2}(0)=50$, serta parameterparameter $\sigma=0,001, \mu_{0}=0,05, \beta_{0}=0,06$, dan $\theta=0,2$.

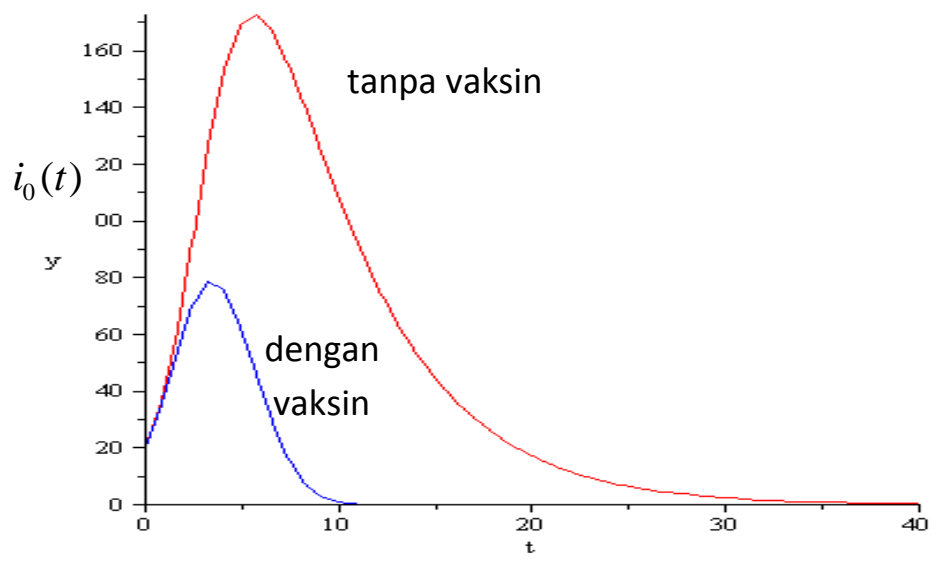

Gambar 2.4 Grafik $i_{0}(t)$ terhadap $t$ tanpa vaksin dan dengan vaksin

Dari gambar tersebut terlihat bahwa dengan adanya vaksin, maka kelompok unggas $i_{0}(t)$ akan lebih cepat menuju nol dibandingkan tanpa vaksin. Hal ini menunjukkan bahwa pengaruh kontrol akan mempercepat penurunan kelompok unggas yang terinfeksi sehingga epidemik dapat dicegah. 


\section{Kesimpulan}

Berdasarkan model penyebaran penyakit flu burung, epidemik pada populasi dipengaruhi oleh kemungkinan kontak antara kelompok unggas rentan dengan kelompok unggas terinfeksi $\left(\beta_{0}\right)$ dan tingkat kematian karena penyakit pada sub populasi unggas $(\theta)$.

Implementasi vaksin pada unggas merupakan salah satu cara untuk mengontrol penyebaran penyakit flu burung. Dengan adanya vaksin, maka populasi $i_{0}(t)$ akan lebih cepat menuju nol dibandingkan tanpa vaksin. Hal ini menunjukkan bahwa pengaruh kontrol akan mempercepat penurunan kelompok unggas yang terinfeksi sehingga epidemik dapat dicegah.

\section{Daftar Pustaka}

Boyce, W. E. dan DiPrima, R. C. 1997 : Elementary Differential Equations and Boundary Value Problems Sixth Edition, John Wiley \& Sons, New York.

Derouich, M. dan Boutayeb, A. 2008 : An Avian Influenza Mathematical Model, Applied Mathematical Sciences, Vol. 2, No. 36, 1749 - 1760.

Edwards, C. H. dan Penney, D. E. 2000 : Elementary Differential Equations with Boundary Value Problems Fourth Edition, Prentice-Hall, New Jersey.

Finizio, N. dan Ladas, G. 1988 : Persamaan Diferensial Biasa dengan Penerapan Modern Edisi Kedua, Erlangga, Jakarta.

Hocking. 1991: Optimal Control: An Introduction to the Theory with Applications. Clarendon Press, Oxford.

Ma, Z. dan Li, J. 2009 : Dinamical Modelling and Analysis of Epidemics, World Scientific Publishing, Singapore.

Situngkir, H. 2004. Epidemiology Through Cellular Automata Case of Study: Avian Influenza in Indonesia, Working Paper WPF2004, Bandung Fe Institute.

Yuliarti, N. 2006 : Menyingkap Rahasia Penyakit Flu Burung, ANDI, Yogyakarta.

Zhao, Y. 2009 : Modelling Avian Influenza in Bird-Human Systems, Massey University, New Zealand. 
